\title{
Silage Crops for Dairy and Beef Cattle II: Sorghum and Other Forage Crops ${ }^{1}$
}

\author{
Marcelo Wallau, Joao Vendramini, Adegbola Adesogan, Diwakar Vyas, and Kevin Korus ${ }^{2}$
}

This publication is a second article on silage crops for dairy and beef cattle that explores crop choices and agronomic aspects of silage production in Florida, from planting until preparing to harvest for sorghum, sorghum x sudan, pearl millet, and cool-season small grain silages. Corn production for silage is covered in Ask IFAS publication SSAGR-69. Information on harvesting, storage, and utilization can be found in Ask IFAS publication SS-AGR-177, Silage Harvesting, Storing, and Feeding (https://edis.ifas.ufl.edu/ publication/AG180). Information on haylage can be found in Ask IFAS publication AN145, Harvesting, Storing, and Feeding Forages as Round Bale Silage (https://edis.ifas.ufl. edu/publication/AN145).

\section{Forage Sorghum}

There are many types and varieties of sorghums (Sorghum bicolor (L.) Moench). The primary types used for silage are forage sorghums, grain sorghums (milo), and sorghumsudan crosses. The sorghum-sudan crosses and pearl millet are better suited for grazing or green chop than for silage (see below). Most commonly, forage sorghum is used for silage because of high biomass production potential compared to grain sorghum. Forage sorghums grow to heights of 5-14 feet with yields similar to corn for the spring crop; however, per-acre yield of total digestible nutrients (TDN) and consequently milk production per acre may be $\sim 35 \%$ lower than corn. When harvested for silage, forage sorghums will produce higher yields than other sorghum types ( 14\%) (Bean et al. 2013) and will contain 20\%-25\% grain, compared to up to $60 \%$ of grain on corn silage. Grain sorghums grow to a height of 3-5 feet. Silage yield of grain sorghums will range from a half to two-thirds of the silage yield of forage sorghums. Grain content of ensiled grain sorghums will average $50 \%-60 \%$ of the total yield; thus, the nutritive value of grain-sorghum silage is only slightly lower than that of corn silage. Sorghum is often a choice on dryland and has lower cost of production than corn, given price of seed and management practices (i.e., requires lower fertilization), and is frequently planted in sequence after corn for a summer crop (fall harvest) in Florida.

Sorghum is also an alternative crop if corn planting is delayed, or conditions are not favorable. One of the main advantages of sorghum is the great capacity to compensate for environmental conditions and mismanagement. Sorghum recovers quickly from unfavorable conditions once resources are available, and unlike corn, it tillers to compensate for lower plant population and closes its canopy more efficiently. Cold fall conditions, however, can result in

1. This document is SS-AGR-461, one of a series of the Agronomy Department, UF/IFAS Extension. Original publication date February 2022. Visit the EDIS website at https://edis.ifas.ufl.edu for the currently supported version of this publication.

2. Marcelo Wallau, assistant professor and forage Extension specialist, Agronomy Department; Joao Vendramini, associate professor and forage specialist, UF/IFAS Range Cattle Research and Education Center; Adegbola Adesogan, professor, Department of Animal Sciences; Diwakar Vyas, assistant professor, Department of Animal Sciences; and Kevin Korus, agricultural Extension agent II, UF/IFAS Extension Alachua County; UF/IFAS Extension, Gainesville, FL 32611.

The use of trade names in this publication is solely for the purpose of providing specific information. UF/IFAS does not guarantee or warranty the products named, and references to them in this publication do not signify our approval to the exclusion of other products of suitable composition.

The Institute of Food and Agricultural Sciences (IFAS) is an Equal Opportunity Institution authorized to provide research, educational information and other services

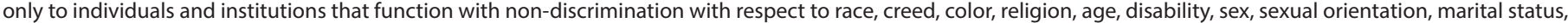

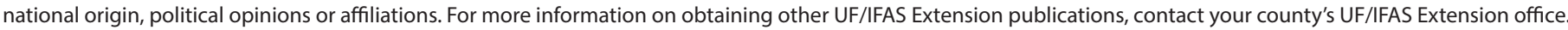
U.S. Department of Agriculture, UF/IFAS Extension Service, University of Florida, IFAS, Florida A \& M University Cooperative Extension Program, and Boards of County Commissioners Cooperating. Andra Johnson, dean for UF/IFAS Extension. 
extended tillering and interfere with the harvesting process when planted too late. Drying down forage sorghum can be a problem. Achieving the desired DM results in harvesting at the hard-dough stage, when the grain kernel is usually too hard to be easily digested by the cow. Such hard-dough sorghums should be processed at the time of harvest. Unless the chopper is equipped with a kernel processor, it frequently escapes the chopping blades and remains intact.

Sorghums, however, can accumulate nitrates and prussic acid after environmental stress. This is especially a problem for cattle grazing certain sorghum hybrids after frosts or droughts. Symptoms, causes, and preventative guidelines are available at https://ufdc.ufl.edu/IR00004776/00001. Detailed information on sorghum production can be found in Ask IFAS publication SS-AGR-333, Forage Sorghum (https://edis.ifas.ufl.edu/ag343). Here, we present a summary of main agronomic aspects of sorghum and complementary information regarding silage production.

\section{Hybrid Selection}

Sorghum hybrid characteristics, such as height, tillering, and nutrient content, and traits, such as brown midrib (BMR), brachytic dwarf, and photoperiod sensitivity, vary widely. The choice of hybrid will depend on desired traits and use. For single-cut silage, the selected hybrid should be tall, sweet stalk plants with a small grain head and limited regrowth potential. When selecting varieties for grazing or multiple cuts, especially sorghum $\mathrm{x}$ sudan hybrids, then strong tillering and regrowth capacity are desirable.

Forage sorghums can be classified into four categories: conventional, brachytic dwarf, BMR, and photoperiod sensitive (Marsalis and Bean n.d.). These traits can be combined in some varieties. Conventional forage sorghums are capable of producing high grain yields, which can result in higher-energy silage, but generally lower forage quality. Some short types are considered "dual purpose" (grain or forage). The brachytic dwarf trait shortens the internodes, making the plant shorter $(<6 \mathrm{ft})$ but with the same number of leaves, and increasing the leaf:stem ratio. This trait also reduces the risk of lodging, which is common for the taller varieties. The BMR is a trait present in many forage crop varieties that reduces the lignin accumulation of the plant and therefore results in greater NDF digestibility. This can result in significant increase in milk production per ton of silage. Some varieties present a brown stalk pith. Brown midrib varieties are typically lower yielding (10\%) and can have more issues with lodging; however, this is varietydependent, and some hybrids perform better than others. You can compensate for lodging by planting at a lower plant population, but it might result in thicker stems. All BMR varieties originated from one of three chemically induced mutations, labeled BMR 6, BMR 12, and BMR 18. Some studies show improved nutritional and productive characteristics for BMR 6 compared to conventional sorghum, but differences are not clear between the different mutations. Photoperiod sensitive plants are tall (up to $14 \mathrm{ft}$ ) and highyielding and remain vegetative until the day length is below 12 hours and 20 minutes, typically around mid-September in Florida. Those plants are more suitable for grazing and hay, and generally have lower quality compared to other options mentioned above. Furthermore, ensiling can be challenging because moisture content is generally too high.

Key factors determining the sorghum hybrids selected for silage are adaptation to local conditions, planting date (i.e., spring or summer), disease and insect tolerance, and productivity. Sorghum is very prone to sugarcane aphids which can reduce yield and nutritive value significantly. Anthracnose and other leaf blights can reduce productivity and quality of silage. Sorghum generally has greater concentrations of soluble sugars compared to corn (sweet stalk). Higher concentration of sugars can enhance fermentation and increase the rate of $\mathrm{pH}$ reduction when ensiling. The UF Forage Team conducts annual hybrid trials to evaluate sorghum production and nutritive value. Information about sorghum and trial results can be found at https://animal. ifas.ufl.edu/extension/courses/csfd/. Note that documents are divided into forage sorghum and sorghum $\mathrm{x}$ sudan, and reported for spring and summer plantings independently.

\section{Planting Date, Population, Row Width, and Depth}

Sorghum is more sensitive to cold temperatures than corn, so planting normally starts after the first of April in north Florida, when chances of cold fronts are minimal and soils are warm. In south Florida, sorghum can be planted as early as February. New plantings can be made into the summer until about 120 days prior to the end of the growing season or to the date of the first frost. Plantings made after midJune will have lower yields than earlier plantings and will suffer more from diseases and insects. Spring plantings, especially in south Florida, made without irrigation may suffer from drought stress. In such situations, sorghum may be the better crop choice compared to corn because sorghum is drought tolerant. Early-planted grain or silage sorghums may make a second or "ratoon" crop but yields of such crops are often less than half of the original harvest, especially if the first harvest was at full maturity. 
Sorghum is normally planted in rows but can also be broadcast. Plant populations for sorghum in Florida range between 70,000 and 100,000 plants per acre, with some companies recommending seeding rates up to 120,000 plants per acre. Higher population ranges are normally acceptable when planting in narrow rows (15-inch) and moisture is not limiting. However, greater plant population generally increases the chance of lodging, especially for BMR varieties, which can reduce production and quality of silage and make for a difficult harvest. Sorghum has a great tillering capability and can compensate for lower planting densities. When broadcasting, the target seeding rate is about $10-15 \mathrm{lb}$ per acre. Most sorghum on dairy farms is planted on 30-inch rows, similar to corn, to facilitate shared use of equipment. Circular cutters on the newer forage heads allow crops to be harvested in wide rows, whether seeds were drilled or broadcast. If harvesting with a single or double-row, tractor-mounted chopper, match row width to the size of the forage chopper head. Regardless of seeding method, seeds should be planted in moist soil at a depth of 1.5 inches and covered.

Seed treatment is very important for sorghum, and in most cases, seeds come with a fungicide, insecticide, and seed safener treatment. Commercial seeds are normally treated with Cruiser ${ }^{\circledR}$ and Gaucho ${ }^{\circledR}$, for example, and this eliminates the need for in-furrow applications of bifenthrin or terbufos (i.e., Counter ${ }^{\circledR}$ ). Counter, however, also has nematicide activity, and can be an alternative treatment in contaminated areas, especially following corn production.

\section{Liming and Fertilization}

Soils should be tested during the fall or winter to determine the kinds and amounts of lime and fertilizers needed.

Sorghums perform best in soils with a $\mathrm{pH}$ of 5.5-6.5. If lime is needed, it should be broadcast and incorporated into the soil during the land-preparation process. Apply all of the soil test-recommended $\mathrm{P}_{2} 0_{5}, 30 \%$ of the recommended $\mathrm{K}_{2} \mathrm{O}$, and $30 \mathrm{lb} \mathrm{N}$ per acre in a preplant or at planting application as a liquid in furrow. Alternatively, this could be sidedressed about a week after planting when plants emerge. Topdress or sidedress the remaining $70 \%$ of the $\mathrm{K}_{2} \mathrm{O}$ and N. Sidedress before plants are too tall to cultivate or approximately four weeks after planting. The maximum $\mathrm{N}$ rate for sorghum recommended by UF/IFAS is $150 \mathrm{lb}$ N/A. If a second ("ratoon") crop is to be attempted, it should be fertilized at about half of the original rate. The fertilizer should be applied immediately after the first harvest. Similar considerations given to corn also apply to effluents for sorghum fertilization.

\section{Pest Control}

Multiple Ask IFAS publications that offer guidelines for pest and disease management are referenced below. For more detailed information, contact your local UF/IFAS Extension agent (http://sfyl.ifas.ufl.edu/find-your-local-office/), and always read the label before applying any pesticide product. Observe harvest or grazing withdrawal periods.

\section{WEEDS}

As with any other crop, weed control in sorghum starts before planting with a clean, prepared seedbed. If planting no-till, proper cover crop management (e.g., rolling and/ or spraying) will provide soil cover and prevent or delay emergence of weeds. Slow growth at the initial stages of sorghum may result in weed problems. Weed control during the initial phases of crop establishment is extremely important and will determine potential yield. Seed safeners like fluxofenim (Concept $\left.{ }^{\circledR}\right)$ or flurazole $\left(\mathrm{Mesh}^{\mathrm{rx}}\right)$, common in most commercial seeds, allow for application of preemergence chloroacetamide herbicides, such as metolachlor (e.g., Dual Magnum ${ }^{\circledR}$, Moccasin $^{\text {Tx }}$ II Plus) and dimethenamid. Without a safener, application of chloroacetamide herbicides will cause root pruning and stunt growth. There are many options when considering postemergence herbicides for sorghum. Pendimethalin (e.g., Prowl $\mathrm{H}_{2} \mathrm{O}^{\circledR}$ ) is commonly used preemergent for extended control of late-season grasses and mixed with atrazine for applications after the 3-leaf stage. Note that forage cannot be grazed or fed within 21 days of application of atrazine. Halosulfuron (Sandea ${ }^{\circledR}$ ) is another common choice for controlling sedges. A comprehensive list of herbicides and instructions can be found in Ask IFAS publication SS-AGR-06, Weed Management in Sorghum (http://edis.ifas.ufl.edu/WG002). Cultivation is another weed management strategy, but it is more time-consuming and expensive. When cultivating, it is important to make sure row width matches cultivator size to avoid crop damage.

\section{INSECTS}

Sorghum is attacked by many of the insects commonly associated with corn. Because sorghum does not have $\mathrm{Bt}$ traits like corn, control of leaf-feeding (i.e., corn earworm, sorghum webworm, and armyworm) insects is essential (Figure 1). Sugarcane aphids are very common and vector diseases such as the barley yellow dwarf virus. Sorghum midge and sorghum webworm may also be a concern to producers. Choosing a hybrid with good insect tolerance and proper seed treatment or applying an in-furrow insecticide is recommended to prevent major insect damage. Nevertheless, as the season advances and the effect of initial systemic insecticides wears off, problems with 
pests can emerge. Corn earworms and armyworms may be present from the seedling stage through maturity. March plantings (first crop) may escape severe infestations, but summer crops can be subject to heavy infestations, especially when following a spring corn crop. Sugarcane aphids are one of the most common issues with sorghum. These can significantly reduce quality and growth. Insecticides used in seed treatments will limit infestation for 30-40 days after planting, after which, other insecticides might be necessary. Pyrethroids are not effective against sugarcane aphids and may harm natural predators. Foliar insecticides such as Sivanto ${ }^{\circledR}$ Prime, Transform ${ }^{\circledR}$ WG, and chlorpyrifos (Lorsban ${ }^{\circledR}$ ) are options for control of sugarcane aphids and other insects. More information can be found in Ask IFAS publication SS-AGR-333, Forage Sorghum (https://edis.ifas. ufl.edu/ag343), as well as in the UGA publication Sorghum Insect Pests and Their Management (https://extension.uga. edu/publications/detail.html?number=B1283).

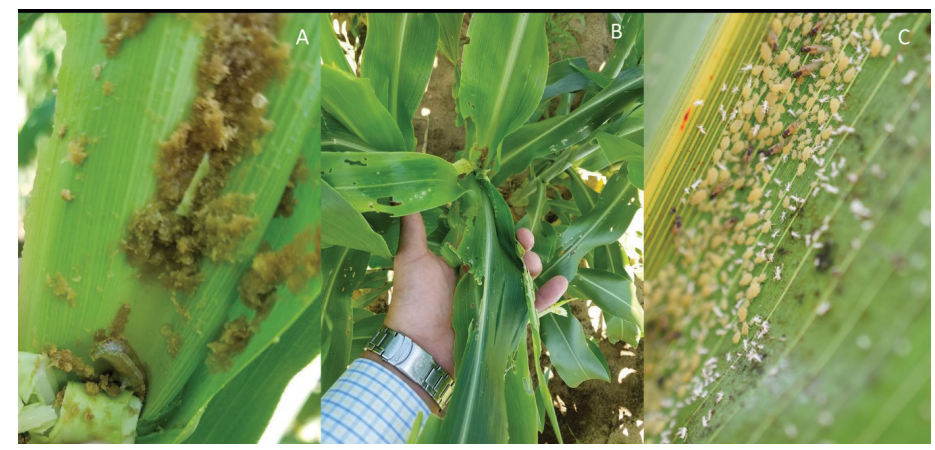

Figure 1. (A) Fall armyworm, (B) fall armyworm damage, and (C) sugarcane aphids in sorghum.

Credits: Marcelo Wallau, UF/IFAS

\section{DISEASES}

The most common diseases affecting sorghum in Florida are anthracnose (Colletotrichum graminicola), grain mold (Fusarium, Curvularia, Colletotrichum, Alternaria, and Bipolaris spp.), head blight, ergot (head smut; Claviceps africana), bacterial leaf stripe (Burkholderia andropogonis), and rust (Puccinia purpurea). Anthracnose can result in yield losses of over 50\% (Acharya et al. 2019) and head mold can potentially produce detrimental or lethal mycotoxins. Most yield loss occurs from stalk rot pathogens such as charcoal rot (the same disease previously discussed with corn). Cultural controls such as planting resistant hybrids, rotating to non-host crops, and tillage are better ways to help prevent fungal and bacterial diseases of sorghum. A general guide for symptoms and management can be found in Ask IFAS publication SS-AGR-333, Forage Sorghum (https://edis.ifas.ufl.edu/ag343).

Pyraclostrobin (Headline ${ }^{\circledR}$ ), pyraclostrobin + fluxapyroxad (Priaxor ${ }^{\circledR}$ ), and azoxystrobin (Quadris ${ }^{\circledR}$ ) are fungicide options for reducing incidence and severity of anthracnose. Nevertheless, fungicide application might not be economical if severity of the disease is low prior to flowering. Research shows that one application of pyraclostrobin or pyraclostrobin + fluxapyroxad is feasible when onset of disease is on or before booting (flowering), and hot, humid weather is anticipated (Acharya et al. 2019). Observe the fungicide withdrawal period for harvesting or grazing before spraying.

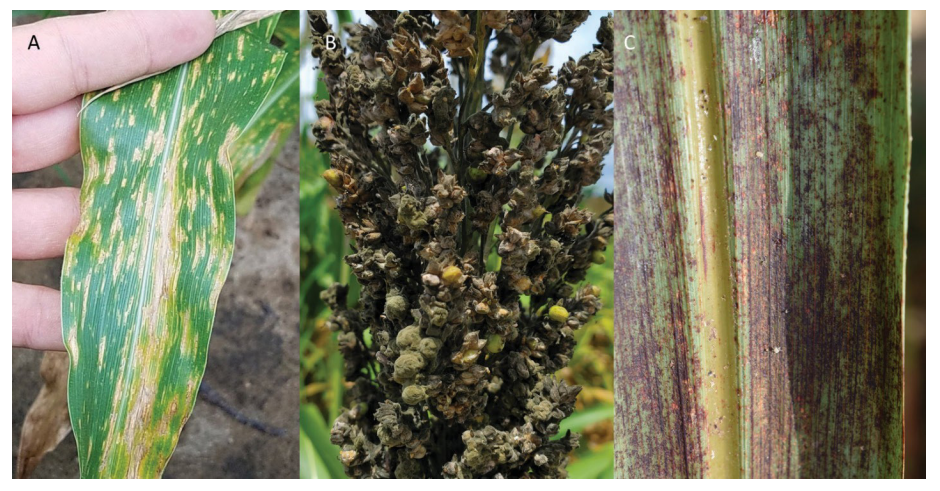

Figure 2. (A) Leaf blight, (B) head mold, and (C) anthracnose on sorghum.

Credits: Marcelo Wallau, UF/IFAS

\section{Harvesting for Silage}

Both grain and forage sorghums should be harvested at $65 \%-70 \%$ moisture and typically at the soft-dough stage of grain maturity. Forage sorghum produces less grain in respect to total biomass, which can limit fermentation. However, hybrids with high concentrations of soluble sugars have improved fermentation compared to traditional types. Digestibility decreases very rapidly in the nongrain-producing types after flowering and can result in low-quality silage. Pay attention to moisture content, as it may be higher than desired to make good silage when harvested at the boot stage. Fall harvest can be challenging as the season extends (tillering) with cooler days in October and longer intervals to reach the desired dry matter concentration. In this case, use of inoculants, additives, or preservatives might be an option for an earlier harvest, in order to maintain quality and avoid butyric fermentation (see https://edis.ifas.ufl.edu/ag180 for more information on silage harvesting and preservation). Stubble of 6-8 inches should be left if a second crop is planned. The cut should prevent shattering of the stubble and keep equipment from running over it. Detailed information on methods and calculations to determine moisture on forage crops can be found in Ask IFAS publication SS-AGR-178, Methods of Forage Moisture Testing (https://edis.ifas.ufl.edu/ag181). 


\section{Sorghum-Sudan and Pearl Millet}

Sorghum x sudan (Sorghum $\times$ drummondii) crosses and pearl millet are considered low-energy crops. They normally produce a leafy forage, grow 3-10 feet tall, and are usually used as a grazing crop or green chop. Some varieties of sorghum-sudangrass produce some grain, but generally do not produce as much grain as forage sorghum varieties (see Hybrid Selection section for more information). Hence, they are adapted to multiple cuts and may not present all the yield potential if used for a single cut as silage. Still, those crops can be ensiled or made into baleage. Sorghum-sudan production follows the same guidelines presented above for sorghum. Ask IFAS publication SSAGR-337, Pearl Millet (Pennisetum glaucum): Overview and Management (https://edis.ifas.ufl.edu/ag347), offers an overview of agronomic characteristics and production practices for pearl millet.

To produce a higher protein silage or haylage, sorghumsudangrass and pearl millet can be harvested when they reach a height of about 3 feet. However, harvesting at this young stage of growth reduces overall yield. Also, in some instances, regrowth has been very poor when plants were harvested at a height of 3 feet, compared to regrowth following harvest at the boot or early-flower stage. For highest yields of digestible dry matter, sorghum-sudangrass and pearl millet should be harvested in the boot to early-flower stage. This means cutting at moisture concentrations greater than $70 \%$, which can result in challenges during ensiling and poor fermentation. Therefore, it may be desirable to add by-products such as dried citrus pulp or some other material to lower the moisture concentration of the silage. Wilting would be desirable, but it tends to be practical only for baleage production. Stems may be too long to be efficiently handled by windrow and pickup equipment, and too much sand may be picked up.

\section{Small Grains and Ryegrass}

The small grains include oats (Avena sativa), rye (Secale cereale), and triticale $(\times$ Triticosecale $)$. These are excellent winter forages that can be planted in sequence after sorghum or corn, to be ensiled, hayed, or grazed. Oats are probably the most popular small grain used for silage because of its high-quality forage, while rye is normally a choice for early chopping. Diseases such as rust and barley yellow dwarf virus frequently pose challenges to oats.

Although rust-resistant varieties are available in the market, new strains of the fungus may make that resistance obsolete within a few years. Rye grows at lower temperatures than oats or wheat and may produce more forage than oats or triticale. However, rye is lower in quality because it produces more stems and fewer leaves. Triticale, a cross between durum wheat and rye, produces very good silage and is similar in quality to common wheat. Ryegrass is normally not recommended for silage in dairy systems, because it does not produce a lot of biomass until later in the season and does not fit in the planting window of corn. Nevertheless, it produces some outstanding forage.

\section{Variety Selection}

Variety selection for small grains is the most important factor for ensuring adequate productivity. A list of cool-season varieties tested and recommended for Florida is available in Ask IFAS publication SS-AGR-84 (https://edis.ifas.ufl.edu/ aa266). This publication is updated annually and includes data from multiple states in the southeastern United States. Aspects to consider when selecting small grain species (or mixture of species) are variety, maturity, and disease resistance. Normally, opting for one species simplifies planting and harvesting procedures, especially because wilting time for varieties is different. Mixtures, however, can be beneficial to reduce insect and disease problems (dilution), enhance productivity, and extend the grazing season. When planting mixes for silage, it is advised to select materials of similar maturity. Generally, rye matures earlier than triticale and oat, but there are large differences within species given different varieties bred for different purposes. More information on maturity and disease resistance is available on our recommendation list.

\section{Planting, Fertilizing, and Pest Management}

Planting dates for cool-season forages range from October 15 to December 15. In north Florida and west Florida, small-grain crops should be planted during the early part of the planting season. In south Florida and central Florida, they should be planted during the last part of the planting season. When planting late, early-maturing varieties are better suited to achieve desirable biomass production, while all can be planted in the earlier dates of the planting window. Very early planting can result in increased challenges from diseases (rust) and insects (fall armyworm), especially for oat when planted during hot and humid days. Delayed germination can cause seed rot, and competition from summer weeds can be overwhelming for small grains. Early planting is recommended only when irrigation is available because fall tends to be dry in most of the state.

Plant about $100 \mathrm{lb} / \mathrm{A}$ of seed on a clean, tilled seedbed, where all the required fertilizer except nitrogen has been incorporated prior to planting. Apply $30-40 \mathrm{lb} / \mathrm{A}$ of $\mathrm{N}$ at 
planting or two weeks after with the complete fertilizer then topdress about 60 days after planting with an additional $60-70 \mathrm{lb} / \mathrm{A}$ of N. Early fertilization (i.e., at early tillering) is essential for a good start and will determine the production potential of the crop. Skipping the first fertilization and only applying at 60 days or later will significantly limit production, while applying all the nitrogen on a single early application will limit response and result in $\mathrm{N}$ loss. Small grains can also serve as dual-purpose crops. These crops can be grazed during the fall and winter. Cattle can be removed in early spring to allow growth for silage production. To successfully do this, the crop must be planted about one month earlier and an additional $50 \mathrm{lb} / \mathrm{A}$ nitrogen topdressing must be made, with the nitrogen going on in two topdressing applications.

Weed management in small grains is mostly related to broadleaf weeds which can be easily and inexpensively controlled with 2,4-D and dicamba products (e.g., Weedmaster $\left.{ }^{\circledR}\right)$. For more details on weed control, see Ask IFAS publication SS-AGR-07, Weed Management in Small Grains Harvested for Grain (https://edis.ifas.ufl.edu/wg009). Before applying any product, check the label for recommendations and preharvest withdrawal period. Fungicides are normally not economical unless rust infestation is very aggressive.

The most common diseases affecting small grains are rust, septoria leaf spot, powdery mildew, ergot, and leaf spot caused by the Helminthosporium complex. Fungicides are rarely used to treat foliar diseases in small grains, and disease incidence and severity is greatly reduced in mixed species stands. If a fungicide is used, it is commonly used to control or prevent rust. The QoI strobilurin group is efficacious in controlling rusts.

\section{Harvesting}

Small grains can be harvested for silage from late-boot to early-dough maturity stages. Dry matter yields will increase, and crude protein percentage will decrease as the plants mature. When harvesting at boot stage, moisture concentration will range from $80 \%-85 \%$ at late-boot, and plants will need to be wilted before ensiling. If waiting until early-dough stage, moisture drops to about $70 \%$ and is satisfactory for direct chopping and ensiling. The optimum dough stage for ensiling may last for only four to six days. For a better compromise between quantity and quality, however, it is recommended to mow at late-boot or earlyhead stage, wilt until moisture is between $50 \%$ and $60 \%$, and then ensile or bale for baleage. Once the plant turns yellow, quality drops rapidly, and the material becomes low in moisture and difficult to pack in the silo.
Harvest rye at the late-boot to early-head stage. If rye goes beyond this stage of maturity, quality decreases rapidly. Although yield is lower compared to cutting at the dough stage, digestible dry matter and crude protein concentrations are higher. Harvesting at this earlier stage of growth and higher moisture content requires additional equipment because the crop must be cut, conditioned, windrowed, and wilted to at least $70 \%$ moisture content before being picked up, chopped, and packed in the silo.

\section{Grass Silage}

Warm-season perennial grasses can be successfully ensiled. There has been an increase in adoption of grass silage due to the advance in machinery and development of new technology. Silage and haylage are feasible alternatives to overcome the weather-related limitations and to conserve warm-season grass as hay in Florida. Despite the high yields produced by perennial warm-season grasses during their growing season, high moisture, low water-soluble carbohydrate concentration, and low water-soluble carbohydrates/buffering capacity ratio may limit the success and subsequent adoption of silage making with these species. There are management practices that have potential to increase the nutritive value of warm-season grass silage. Dry matter concentration affects bacteria, rate of fermentation, and amount of carbohydrates needed for complete fermentation. Fermentation is restricted as dry matter concentration increases. For this reason, it is necessary to wilt warm-season grasses to approximately $50 \%$ dry matter concentration to obtain desirable fermentation rates.

Microbial fermentation inoculants are used in silages primarily with the intent of shifting acid production in the direction of lactic vs. acetic, improving fermentation efficiency, recovering dry matter, and improving animal performance. Unlike silage in many temperate areas, silage made from warm-season grasses in tropical and subtropical areas is characterized by relatively high concentration of acetic acid. Acetic acid is not as strong an acid as lactic, and its accumulation buffers against a decline in silage $\mathrm{pH}$ below 4.8. The results of using inoculants in corn or coolseason forages have been positive; however, the results have been less consistent for perennial warm-season grasses. Some additives, such as molasses and propionic acid, are effective to improve fermentation characteristics of warmseason grass silages.

There are practical recommendations to optimize the fermentation of grass silage in Florida: 1) wilt forage to $50 \%$ $\mathrm{DM} ; 2)$ remove the bales from the field and wrap immediately after baling; and 3) wrap with a minimum of 6 layers 
of plastic. Keeping the plastic intact minimizes losses after the fermentation is stable. Specific management practices for different warm-season grass species, such as bahiagrass, bermudagrass, stargrass, and limpograss, can be found at https://edis.ifas.ufl.edu/.

\section{Legume Silage}

Alfalfa, red clover, and other hay-type, cool-season legumes-either alone or in combination with grass-have some potential as silage crops. When harvested at the optimum growth stage, these crops are high in crude protein but low in water-soluble carbohydrates. Therefore, these crops need to be wilted to $50 \%$ moisture to decrease detrimental water activity in the silage. In addition, legumes have high buffering capacity, which limits the necessary drop in $\mathrm{pH}$ and may result in appearance of undesirable microorganisms, such as yeast and mold. Summer legumes such as aeschynomene, hairy indigo, alyceclover, perennial peanut, annual peanut, cowpea, pigeon pea, and forage soybean can also be ensiled. These forages should also be wilted to $50 \%$ moisture and stored after application of a silage aid that improves lactic acid formation, such as ground corn, molasses, and propionic acid. Specific management practices for different legume species can be found at https://edis.ifas.ufl.edu/.

\section{References}

Acharya, B., T. O’Quinn, W. Everman, and H. Mehl. 2019. "Effectiveness of Fungicides and Their Application Timing for the Management of Sorghum Foliar Anthracnose in the Mid-Atlantic United States." Plant Disease 103(11): 2804-2811. doi:10.1094/pdis-10-18-1867-re

Bean, B. W., R. L. Baumhardt, F. T. McCollum, and K. C. McCuistion. 2013. "Comparison of Sorghum Classes for Grain and Forage Yield and Forage Nutritive Value." F. Crop. Res. 142:20-26. doi:10.1016/j.fcr.2012.11.014.

Marsalis, M. A., and B. Bean. n.d. Western Forage Production Guide, United Sorghum Check Off Program. https:// www.sorghumcheckoff.com/assets/media/productionguides/westforageguideforweb092611.pdf 
Table 1. Summary of recommendations for silage crops in Florida.

\begin{tabular}{|c|c|c|c|c|}
\hline Crop & Planting Dates ${ }^{2}$ & Seeding Rates (Ib/A) & When to Cut ${ }^{3}$ & \% Moisture As Cut \\
\hline Corn & $\begin{array}{l}\text { S, Feb. 1-Mar. } 15 \\
\text { N, Feb. 15-Apr. } 15\end{array}$ & $\begin{array}{l}\text { As needed to provide more than } \\
\text { 20,000-35,000 plants/A }\end{array}$ & $\begin{array}{l}\text { Take samples to determine } \\
\text { moisture content. When the kernel } \\
\text { milk line is about } 1 / 2-2 / 3 \text { of the } \\
\text { way down the grain. Cut at } 65 \% \\
\text { moisture. }\end{array}$ & 65 \\
\hline Forage sorghum & $\begin{array}{l}\text { S, Mar.-Jul. } \\
\text { N, Mar.-Jun. }\end{array}$ & $\begin{array}{l}\text { 6-8 } \\
\text { (in rows only, target 75,000- } \\
120,000 \text { plants/A; follow } \\
\text { company's recommendations) }\end{array}$ & $\begin{array}{l}\text { When first seed heads reach soft- } \\
\text { dough stage. }\end{array}$ & 70 \\
\hline Grain sorghum & $\begin{array}{l}\text { S, Mar.-Jul. } \\
\text { N, Mar.-Jun. }\end{array}$ & $\begin{array}{l}6-8 R^{4} \\
10-15 B C\end{array}$ & $\begin{array}{l}\text { When first seed heads reach soft- } \\
\text { dough stage. }\end{array}$ & 70 \\
\hline Sorghum-sudangrass & $\begin{array}{l}\text { S, Mar.-Jul. } \\
\text { N, Mar.-Jun. }\end{array}$ & $\begin{array}{l}8-10 \mathrm{R} \\
24-30 \mathrm{BC}\end{array}$ & $\begin{array}{l}\text { From boot stage until seed heads } \\
\text { begin to appear; add preservative. }\end{array}$ & $70-80$ \\
\hline Sorghum-sudangrass & $\begin{array}{l}\text { S, Mar.-Jul. } \\
\text { N, Mar.-Jun. }\end{array}$ & $\begin{array}{l}8-10 \mathrm{R} \\
24-30 \mathrm{BC}\end{array}$ & $\begin{array}{l}3 \text { feet in height; possible multiple } \\
\text { cuts per season. }\end{array}$ & 80 \\
\hline Pearl millet & $\begin{array}{l}\text { S, Mar.-Jul. } \\
\text { N, Mar.-Jun. }\end{array}$ & $\begin{array}{l}8-10 \mathrm{R} \\
24-30 \mathrm{BC}\end{array}$ & $\begin{array}{l}\text { From boot stage until seed heads } \\
\text { begin to appear; possible multiple } \\
\text { cuts per season; add preservative. }{ }^{5}\end{array}$ & 80 \\
\hline Rye & Nov. 15-Dec. 15 & 100 & Late boot ${ }^{6}$ to early head. & $70-80$ \\
\hline Oats & Nov. 15-Dec. 15 & 100 & Early soft dough to dough stage. & 70 \\
\hline Wheat & Nov. 15-Dec. 15 & 100 & Early soft dough to dough stage. & 70 \\
\hline Triticale & Nov. 15-Dec. 15 & 100 & Early soft dough to dough stage. & 70 \\
\hline Summer annual legumes & Apr. 1-Jun. 30 & --- & Pre-flower. ${ }^{6}$ & 80 \\
\hline Winter legumes (Alfalfa) & $\begin{array}{l}\text { S, Oct. } 15-\text { Dec. } 1 \\
\text { N, Oct. 1-Nov. } 15\end{array}$ & --- & First flower. ${ }^{6}$ & 80 \\
\hline Perennial grass & --- & --- & $\begin{array}{l}\text { Take first cut when } 14-16 \text { inches } \\
\text { of growth have been accumulated, } \\
\text { then every } 4-6 \text { weeks. }{ }^{6}\end{array}$ & $75-80$ \\
\hline \multicolumn{5}{|c|}{$\begin{array}{l}{ }^{1} \text { Use recommended varieties and fertilize according to soil-test recommendation. } \\
{ }^{2} \mathrm{~S}=\text { South Florida; } \mathrm{N}=\text { North Florida. } \\
{ }^{3} \text { For maximum yield of digestible dry matter, with exception of sorghum-sudangrass harvested at 3-feet height. } \\
{ }^{4} \mathrm{R}=\text { Rows; } \mathrm{BC}=\text { Broadcast. } \\
{ }^{5} \mathrm{Add} \text { citrus pulp, a lactic acid-producing inoculant, or another suitable preservative to improve the ensiling process. } \\
{ }^{6} \text { Wilt to } 60 \%-70 \% \text { moisture; if moisture is lower than } 60 \% \text {, add a lactic acid-producing inoculant or a suitable preservative. }\end{array}$} \\
\hline
\end{tabular}

